------ Raf. J. Sci., Vol. 27, No.4, pp.57-65, 2018------

\title{
Calculate and Analysis of Air Mass and Solar Angles of Mosul City
}

\author{
Taha M. Al-Maula \\ Abdullah I. Al-Abdulla \\ Department of Physics/ College of Science/ University of Mosul \\ E-mail: tahamustafa@yahoo.com E-mail: abdullaed@yahoo.com.
}

(Received 16/4/2018; Accepted 12/6/2018)

\begin{abstract}
The solar radiation energy of the city of Mosul was calculated according to the value of $\mathrm{AM}=$ 1.24 on 21 March and September, theoretically using formula 7 and measuring it practically using the radiometer of the intensity of the optical radiation emitted from the solar simulator that was designed in the laboratory. There are values of $982 \mathrm{~W} / \mathrm{m}^{2}$ and $996 \mathrm{~W} / \mathrm{m}^{2}$, respectively, comparing these values in Table 1 with published values for other sites. Table (1) AM values and solar radiation intensity theoretically using formula (7) and practically for different angular values.

For the purpose of solar simulators manufacturing, the air mass (AM) were calculated for the city of Mosul at Altitude line $\left(36.35^{\circ}\right)$ and Longitude line (43.100) and at a height of 220 meters above sea level, this required the computation of the Solar inclination angle $(\delta)$, the hour angle $\left(W_{z}\right)$, the Solar elevation angle $(\mathrm{h})$ and the zenith angle $(\mathrm{Z})$, in addition to that, the calculations were studied in specified day, chosen at the $21^{\text {st }}$ of each month From sunrise to sunset, which is the daylight hours. The study showed that, the values of AM become equals to one at twelve o'clock and 1.24 on the 21 st of March and September when the sun at the zenith angle $36.35^{\circ}$. Also it has been found that the variation of the angle of solar elevation and daylight hours rise to its maximum values at noon and then decreases gradually with daylight hours even the sunset hours. Also the zenith angle and daylight hour's decreases gradually to its minimum value at solar noon time and then rise again at the sunset hours. also it has been found that the relationship between the air mass values vary daily by changing the values of daylight hours.

The results show Vary daily by changing the values of daylight hours the AM values decreases with the solar elevation angle while its values increase with zenith angle. The values of AM have been computed for both daylight hour and hour angle its value decreases to minimum value at noon and raise the value of AM again at the end of daylight hour. The curves profile of AM variation with solar angle and zenith angle are of similar behavior with the published for other locations. The standard value of $\mathrm{AM}$ for Mosul City that adopted in this research work at altitude line $36.35^{\circ}$ is equal to 1.24 on the $21^{\text {st }}$ of March and September and 1.03 on the $21^{\text {st }}$ of June and 1.8 on the $21^{\text {st }}$ of December.
\end{abstract}

Keywords: Solar Simulator, Solar Simulator manufacturing, Air Mass, Air Mass calculations.

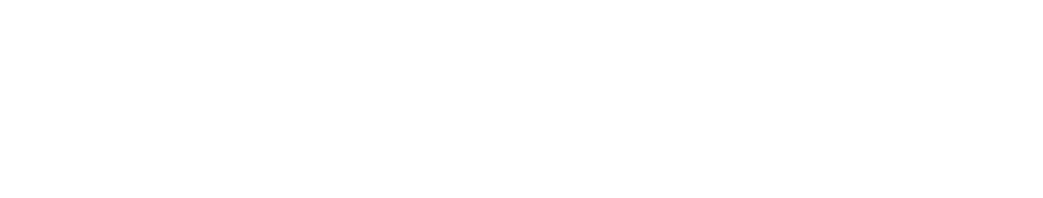

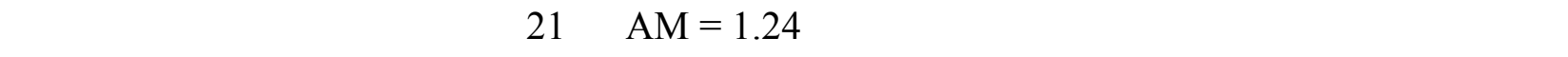
(7) وقيلسها عملها بلستخدلم مقيلس الطاقة الإثعاعية لشدة الإثشعاع الضوئي الخارج من المحلكي الشمسي التي مق تصميمه في 
المختبر. هنك قيم تساوي (982 W/m² $92 \mathrm{~m}^{2}$ ( 996 ) على التوالي ، مقارنة هذه القيم في الجدول 1 مع القيم المنشورة للمواقع الأخرى. الجدول 1: قيم AM وكثلفة الإثعاع للثمسي ظظريا بلستخدلم الصيغة (7) وعمليا للقيم المختلفة لزاوية. لغرض تصنبع محلكيشمسي، م مسلب الكتلة الهوائية (AM) لمدينة الموصل الواقعة على خط عرض (36.35 ) وخط

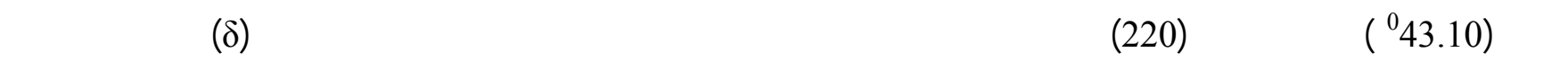
(Ws)، زاوية الارتفاع للشمسي (h) وزاويةسمت الرلس (Z). العملية الهسابية لجريت ليوم محدد، وهويوم 21 من كل ششهر من

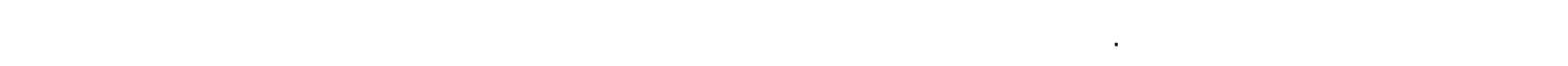

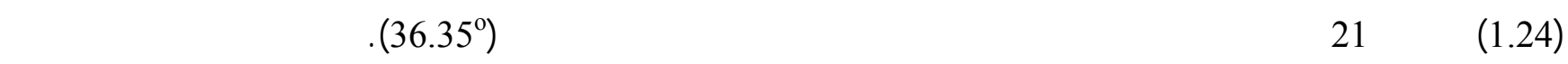
الارتقاع الثطسي وساعلت النهار يزداد تدريجيا إلى أن يصل أقصى قيمة له عند الظهيرة ثم ينخفض تدريجيا معساعلت النهار حتىساعلت الغروب. ووجد أيضا لن العلافة بين قيم الكتلة الهوائية وساعلت النهار والزاوية للساعية تختلف يوميا بتغير قيم

ساعلت النهار. لظهرت النتائج أن قيم الكتلة الهوائية تتخغض مع زاوية الارتقاع الثمسي بينما تزداد قيمتها مع زاوية للسمت الشمسي لآن قيمتها عندسمت الرلس تساوي ولحد لذا كلما البتعنا عنسمت الرلس تزداد قيمة الكتلة الهوائية. وأيضا وجد ان قيمة الكتلة الهوائية للكل منساعلت النهار والزاوية للساعية يقل تدريجيا اله القل قيمة لها عند الظهيرة وتزداد تلك القيم مجددا حتى نهاية ساعلت النهار. إنسلوك المنحنيت تغير بتغير قيم AM مع زاوية الارتقاع للثمسي وزاويةسمت الرلس يتوافق مع ما م ششره

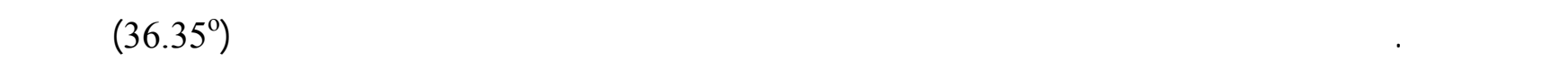
مساوية ل ـ 1.24 في يوم 21 منشهري آذار وأيلول و(1.03) في يوم 21 منشهر حزيران و(1.8) في يوم 21 منشهر كانون الأول.

الهامل الدالة: المحلكي الثمسي، تصنبع المحلكي الثمسي، الكتلة الهوائية، هسابلت الكتلة الهوائية.

\section{INTRODUCTION}

Air Mass (AM) value is an important parameter for manufacturing the solar simulator as calibration factor refers to the path length of the solar beam through the atmosphere and depends on the solar zenith angle. AM is important because with longer path length there is more opportunity for scattering and absorption of solar radiation by atmospheric constituents. Sun angles vary with latitude, time of the day and day of the year, therefore latitude time and day of the year are varied in the calculations shown later to account for AM effects (Hulstrom et al., 1985).

Air Mass is 1.0 when the sun is directly overhead, 1.5 when the sun is $48.2^{\circ}$ from vertical and 2.0 when the sun is at $60.0^{\circ}$ (Faine et al., 1990). The two ASTM AM 1.5 standard spectra were modeled for a direct-normal case and for global case where the collector surface is south- facing and tilted $37.0^{\circ}$ from the horizontal, the direct-beam incidence angle is $11.2^{\circ}$ for the case, therefore represent the case when the solar zenith angle is $48.2^{\circ}$ because the collector surface for the global case is south facing at a $37.0^{\circ}$ tilt, the incidence angle is $48.2^{\circ}$ minus $37.0^{\circ}$ or $11.2^{\circ}$ (Faine et al., 1990).

The aim of this work is to determine the value of the AM coefficient for Mosul city and consider it as standard for future theoretical and practical investigations concerning the photovoltaic applications. 


\section{THEORITICAL CONSIDRATION}

Solar angle is defined as the direction of the sun at any point of the Earth's surface. It's necessary to determine the location of the sun for the Earth. The latitude $(\varphi)$ is the angle which measured at the center of the Earth between the Equator plane and our position. It's expressed either north or south, and varies from $0^{\circ}$ to $90^{\circ}$. Solar angles including the hour angle $\left(W_{s}\right)$, solar inclination angle $(\delta)$, solar elevation angle (h), Zenith angle (z) and horizontal angel of the sun (A) as shown in the Fig. (1).These angles depend on the latitude, day number, The day time (Muhammad, 1983), (Edwords and Hildebrand, 2005).

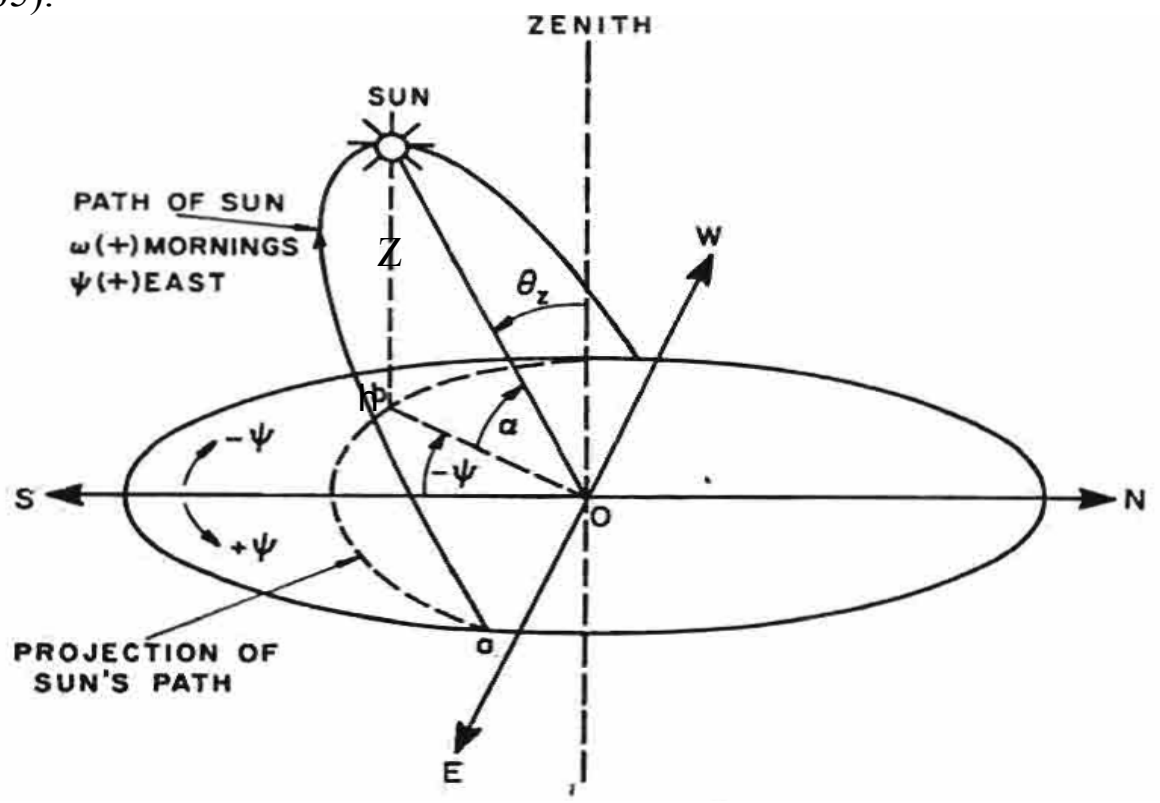

Fig. 1: Dfinition of sun's zenith, elevation, and azimuth angles.

The hour angle $\left(\mathrm{W}_{\mathrm{g}}\right)$ is the angular measurement of time and it is equal to $15.0^{\circ}$ per hour, which is measured for the location of the sun. Time value for any daylight hour, can be measured from the following relationship.

$$
W_{s}=\frac{360}{24}(12-\mathrm{t})
$$

Where: $t$, the hourly rate of time which is measured from the time of the back.

So the hourly angle is positive before noon and negative after noon but equal to zero at noon (Sukhatame, 2004).

The angle between the line joining the centers of both the sun with the earth and its projection onto the equatorial plane is called the Solar inclination angle $(\delta)$ (Spencer, 1971). Which can be calculated from the following relationship (Cooper, 1969):

$$
\delta=23.45 \sin \left[\frac{360}{365}\left(\mathrm{~d}_{\mathrm{n}}+284\right)\right] \text {. }
$$

$\mathrm{d}_{\mathrm{n}}$ : is the day number of the year.

The variation of inclination angle $(\delta)$ with the day number of the year $\left(\mathrm{d}_{\mathrm{n}}\right)$ are illustrated in Fig. (2) (Rongere, 2008). 


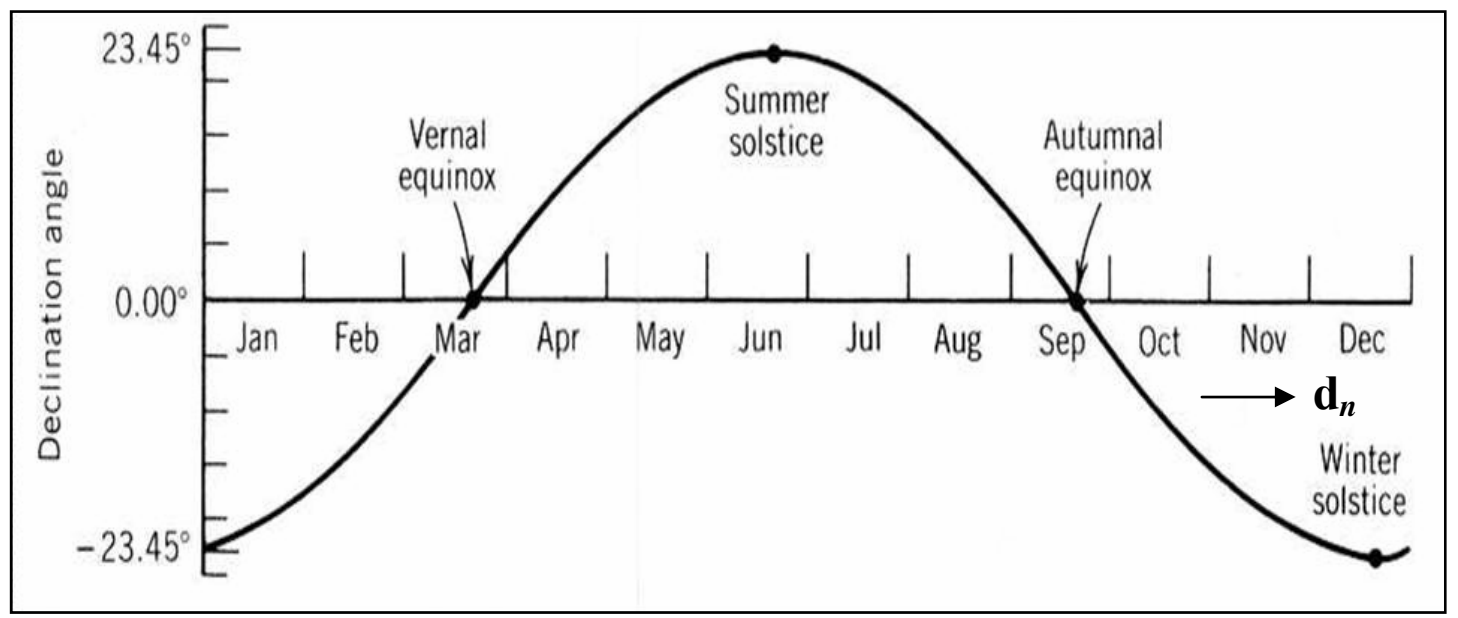

Fig. 2: The variation of the inclination angle $(\delta)$ as a function of the sequence of the day number of the year $\left(d_{n}\right)$.

Solar Altitude Angle (h) is the angle between horizontal plane and line joins the site with the sun centers (sun elevation). The angular height measured from the observer's horizon to the position of the sun in the sky. The important of those angles are to determining the amount of radiation reaching the surface of the earth. solar elevation angle (h) can be calculated from the equation (Hulstrom et al., 1985):

$$
h=\sin ^{-1}\left[\sin \varphi \sin \delta+\cos \varphi \cos \delta \cos w_{s}\right]
$$

The zenith angle $(Z)$ is the angle between the local observer normal and the line joining the observer to the sun. It is an angle between $0^{\circ}$ and $90^{\circ}$ and it is calculated from the equation (Hulstrom et al., 1985):

$$
\mathrm{Z}=90^{\circ}-h
$$

The air mass (AM) coefficient is a measure of the length of the optical path in which sunlight have to traverse in order to reach the surface of the Earth which expressed relative to the path length of vertical inclination normal to the surface, which is represented by Zenith angle. The AM number describes the accurately for angles of incidence up to around $75^{\circ}$ (Green, 1982). AM is calculated by the following equation (Rhode, 2007):

$$
\mathrm{AM}=1 / \cos (\mathrm{Z})
$$

If refraction is ignored, the path AM of a light ray at zenith angle $(Z)$ through a radially symmetrical atmosphere of height $Y_{\text {atm }}$ is given by (Schoenberg, 1929):

$$
A M=\left(r^{2} \cos (Z)+2 r+1\right)^{\frac{2}{2}}-r \cos (Z)
$$

Where $r$ is the ratio between the radius of the earth to the radius of the atmosphere.

The solar irradiation power can be calculated theoretically depending on the value of AM at any position by using the following formula (Meinel and Meinel, 1976):

$$
I=1.1 * I_{0} *(0.7)^{(A M)^{(0.670)}}
$$

Where $\mathrm{I}_{\mathrm{o}}$ the solar intensity external to the Earth's atmosphere equals $1.353 \mathrm{~kW} / \mathrm{m}^{2}$ and the factor of 1.1 is derived assuming that the diffuse component is $10 \%$ of the direct component. 


\section{RESULTS AND DISCUSION}

The latitude angle $(\varphi)$ specifies the location and takes respectively positive and negative values in the northern and southern hemispheres. The earth rotates around the sun in an elliptical orbit tilted at $23.441^{\circ}$ with respect to the celestial equator (Wilson and Van Sweey, 1942), and the instantaneous position of the sun is described by an angle called hour angle $\left(W_{x}\right)$ representing the distance between the meridian passing through the sun and the meridian of the place. This angle is zero at noon; it increases toward the east in the afternoon and decreases toward the west in the morning. It gets incremented of $15^{\circ}$ for each hour following the longitudinal direction and it is attributes both the positive values before noon and the negative values after noon (Mousazadeh et al., 2009). The solar inclination angle $(\delta)$ equal to zero at the vernal and autumnal equinoxes and has a value of approximately $+23.5^{\circ}$ at the summer solstice and about $-23.5^{\circ}$ at the winter solstice. The air mass (AM) were calculated for the city of Mosul at Altitude line $\left(36.35^{\circ}\right)$, the calculations were studied at specified days which were chosen at the $21^{\text {st }}$ of each months, From sunrise to sunset this is required for the computation of the daylight hours with the hour angles, solar inclination angle, solar elevation angle and the zenith angle. The study showed that the solar elevation angle (h) increases gradually with the daylight hours $(t)$ to its maximum value to the 12.0 at noon and then decreases gradually to its minimum value at sunset, the values of (h) varied for each month, as illustrate in the Fig. (3).

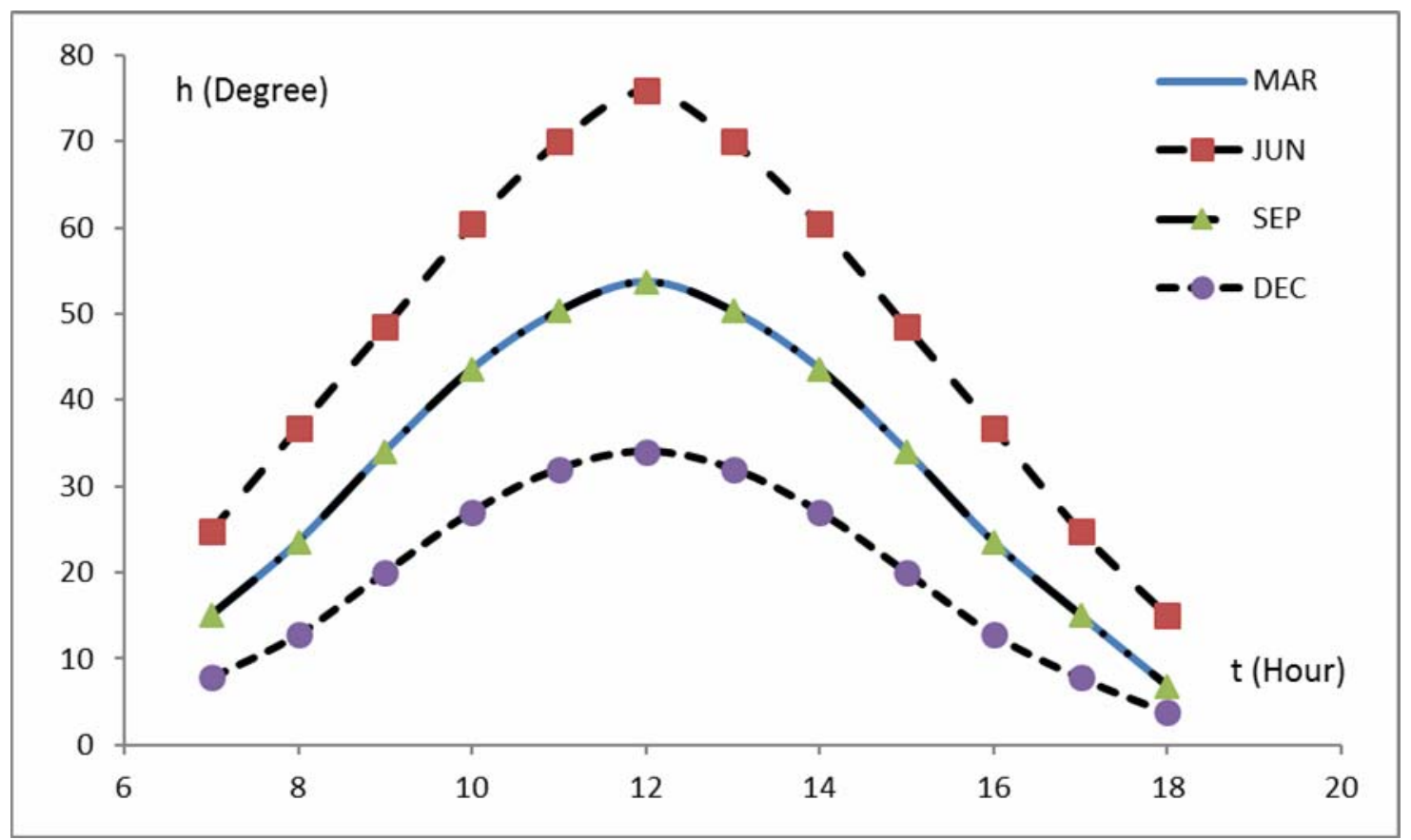

Fig. 3:The hourly (t) Variation with the solar elevation angle (h) for Mosul city of the months, March, Jun, September and December.

While the zenith angle decreases with the daylight hours ( $t$ ) to its minimum value to the 12.0 at noon and then increases again to its maximum value at sunset hours the values of $(Z)$ varied for each month, as illustrate in the Fig. (4). 


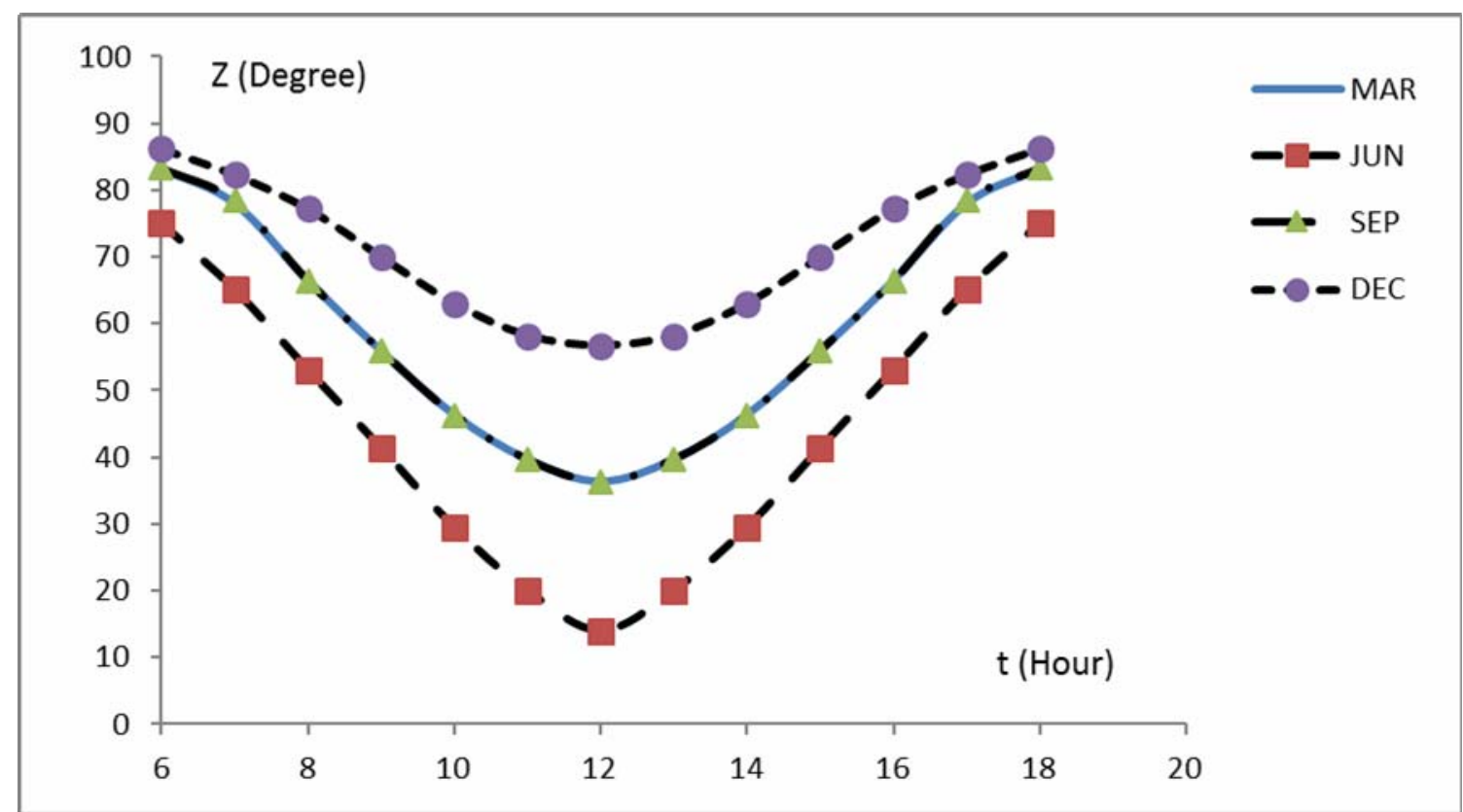

Fig. 4: The hourly (t) Variation with the zenith angle (Z) for Mosul city of the months, March, Jun, September and December.

Farther more AM values for daylight hour (t), its value decrease to the minimum value at noon and then increases again at sunset hours as shown in the Fig. (5).

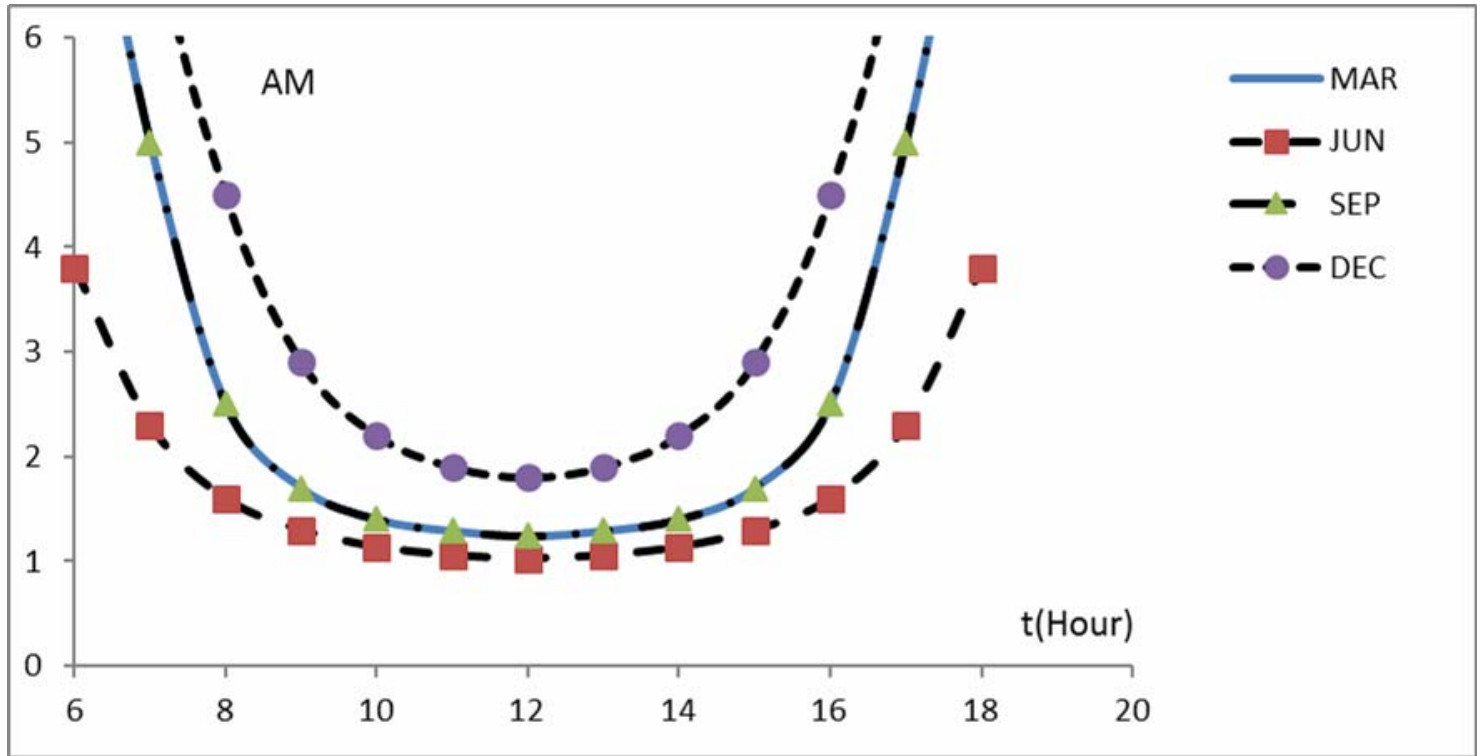

Fig. 5: The hourly (t) Variation with the AM for Mosul city of the months, March, Jun, September and December.

In addition to that, the variation of AM values with solar elevation angle ( $h$ ) has been demonstrated in Fig. (6) where the values of AM decrease with the solar elevation angle, these values varied for each month. 


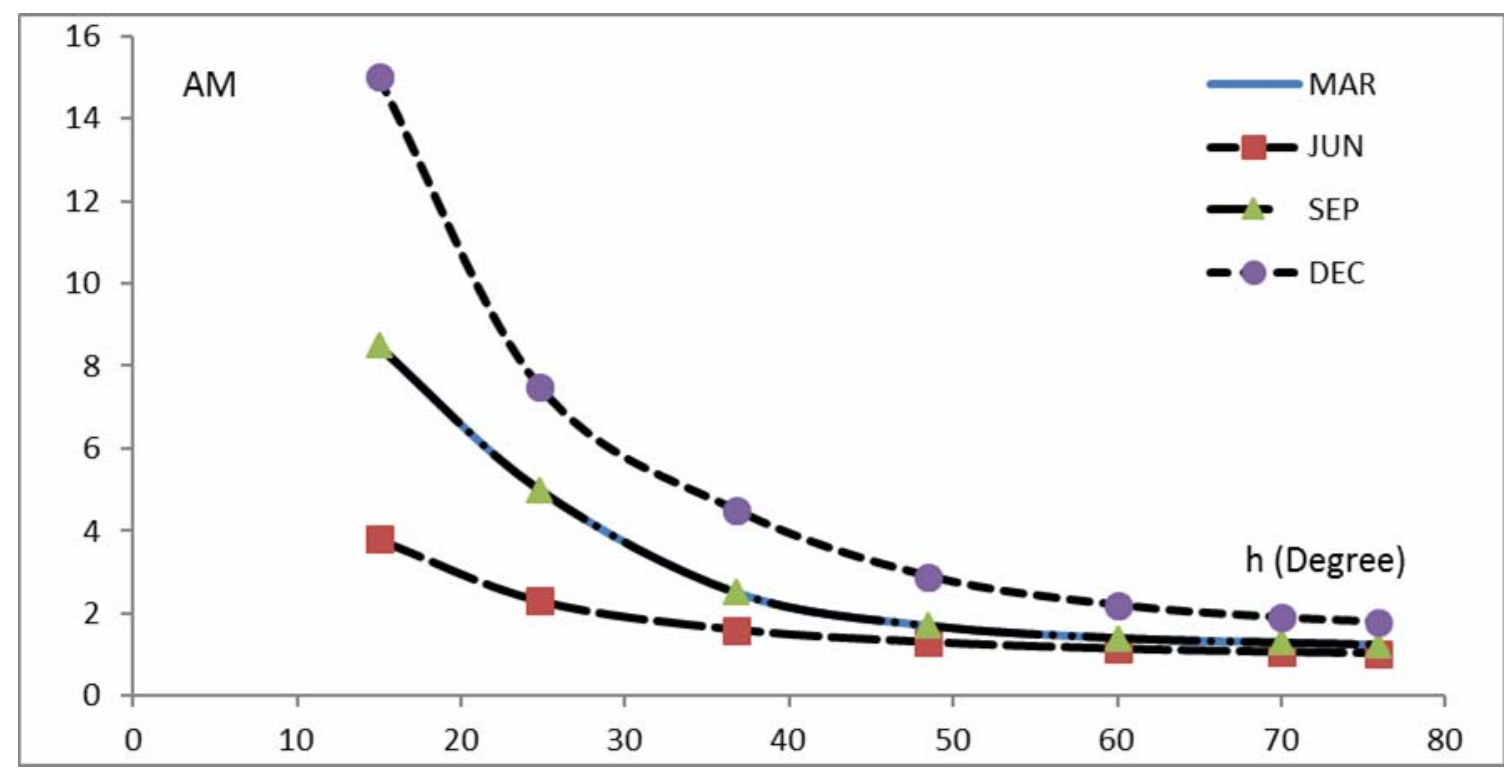

Fig. 6: Variation of the Air mass (AM) with the solar elevation angle (h), for Mosul city of the months, March, Jun, September and December.

While the variation of AM values with zenith angle $(Z)$ has been demonstrated in Figure (7) its values increase with zenith angle, these values varied for each month too.

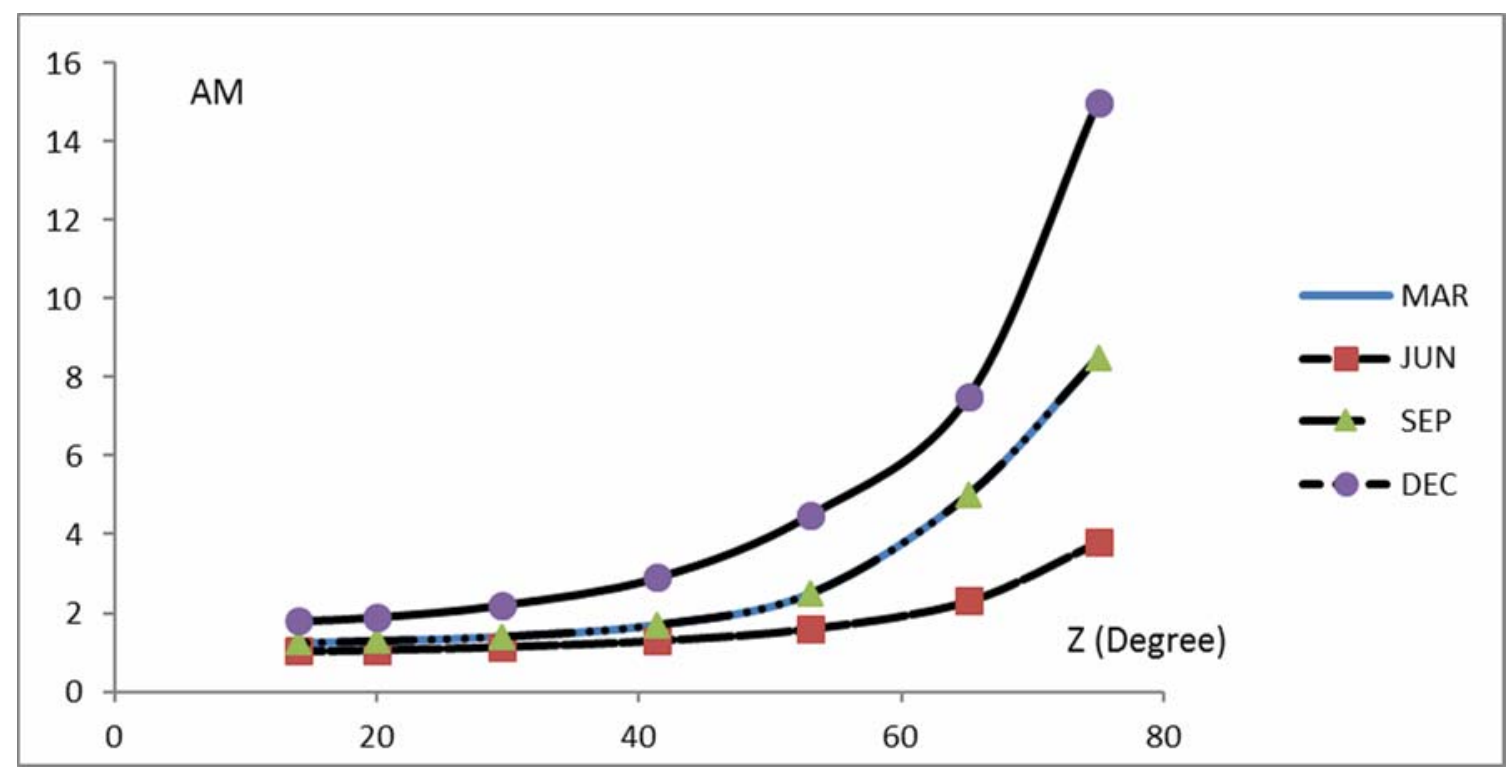

Fig. 7: Variation of the Air mass (AM) with the zenith angle (Z), for Mosul city of the months, March, Jun, September and December.

The above results of the curves profile agreed with the published for other regions (Schoenberg, 1929), (Faine et al., 1990).

The solar irradiance power has been calculated for Mosul city according to the value of AM = 1.24 on the $21^{\text {st }}$ of March and September, theoretically using formula (7) and measured practically 
using irradiance power meter. There values are equal to $\left(982 \mathrm{~W} / \mathrm{m}^{2}\right)$ and $\left(996 \mathrm{~W} / \mathrm{m}^{2}\right)$ respectively, these values compared in Table 1 with the published values for other locations.

Table 1: The values of AM and solar irradiance intensity theoretically using formula (7) and practically of different values of Zenith angle (Meinel and Meinel, 1976).

\begin{tabular}{|c|c|c|c|}
\hline Zenith angle (Degree) & $\mathbf{A M}$ & $\begin{array}{l}\text { Theoretical Irradiance } \\
\qquad\left(\mathbf{W} / \mathbf{m}^{2}\right)\end{array}$ & $\begin{array}{c}\text { Practical Irradiance } \\
(\mathrm{W} / \mathrm{m} 2)\end{array}$ \\
\hline- & 0 & 1353 & - \\
\hline $0^{0}$ & 1 & 1040 & - \\
\hline $23^{0}$ & 1.09 & 1020 & - \\
\hline $30^{0}$ & 1.15 & 1010 & - \\
\hline $36.35^{\circ}$ & 1.24 & 982 & 996 \\
\hline $45^{0}$ & 1.41 & 950 & - \\
\hline $48.2^{0}$ & 1.5 & 930 & - \\
\hline $60^{\circ}$ & 2 & 840 & - \\
\hline $70^{0}$ & 2.9 & 710 & - \\
\hline $75^{0}$ & 3.8 & 620 & - \\
\hline $80^{\circ}$ & 5.6 & 470 & - \\
\hline $85^{0}$ & 10 & 270 & - \\
\hline $90^{\circ}$ & 38 & 20 & - \\
\hline
\end{tabular}

\section{CONCLUSIONS}

The value of AM decreases as the solar elevation angle increases while its value increase with zenith angle. Farther more AM value computed for daylight hour and hour angle, its value comply with published for other regions.

The calculations were studied in a specified day, the $21^{\text {st }}$ of each month at daylight hours From sunrise to sunset. The value of AM chosen in this study equals to 1.24 at Mosul city where the sun is at altitude equals to $36.35^{0}$ from vertical.

According to the values of $A M=1.24$, the solar irradiation intensity were calculated theoretically and measured practically and there values are equals to $\left(982 \mathrm{~W} / \mathrm{m}^{2}\right)$ and $\left(969 \mathrm{w} / \mathrm{m}^{2}\right)$ respectively and of good agreement.

\section{REFERENCES}

Cooper, P.I. (1969). The absorption of solar radiation in solar stills. Sol. Energy. 12(3), 333-346.

Edwards, W.N.; Hildebrand, A.R. (2005)." Solar Energy". University of Calgary, Dept. of Geology and Geophysics, University Drive N.W., Calgary, Alberta, Canada.

Faine, S.P.; Kurtz, R.; Riordan,C.; Olson, J.M. (1990). "The Influence of Spectral Solar Irradiance Variations on the Performance of Selected Single-Junction and Multijunction Solar Cells". Solar Cells, 31 received november 20. Original Research Article, pp. 259-278.

Green, M.A. (1982). "Solar Cells: Operating Principles Technology and System Applications. PrenticeHall". 
http://www.engr.sjsu.edu/mae/faculty/rongere/Solar_2008. ppt, cited by Rongere, F.X. (2008). "Solar Energy". San Jose State University.

http://www.srrb.noaa.gov/highlight/sunrise/azelzen.gif.

http://www.engr.sjsu.edu/mae/faculty/rongere/Solar_2008. ppt, cited by Rongere, F.X. (2008).

Hulstrom, R.; Bired, R.; Riordan, C. (1985). Photo thermal oxidative destruction of chloronaphthalene. Sol. Cells., 15, pp. 365-391.

Meinel, A.B.; Meinel, M.P. (1976). " Applied Solar Energy". Addison Wesley Publishing Co. 57p.

Mousazadeh, H.; Keyhani, A.; Javadi, A.; Mobli, H.; Abrinia, K.; Sharifi, A. (2009). A review of principle and sun-tracking methods for maximizing solar systems output. Renew Sustain Energy Rev., 13,1800-18.

Muhammad, I.M. (1983). "An Introduction to Solar Radiation". Academic press Canada

Rhode, R. (2007). "Solar Spectrum". Global Warming Art. Retrieved from"Solar Energy". San Jose State University.

Schoenberg, E. (1929)." Theoretische Photometric", Über die Extinktion des Lichtes in der Erdatmosphäre in Handbuch der Astrophysik. Band II, erste Hälfte. Berlin: Springer.

Shojaee, S.; Moravians, M.; Manhood, M. (2015). Numerical investigation of wind flow around a cylindrical trough solar collector. J. Power and Energy Engi., 3, 1-10.

Spencer, J.W. (1971). Fourier series representation of the position of the Sun. Fourier series Representation of the Position of the Sun, Search., 2(5), 172-172.

Sukhatame, S.P. (2004). "Solar Energy", $2^{\text {nd }}$ ed., Tata McGraw Hill Publishing Company Limited, Tenth reprint.

Wilson, M.J.; van Swaay, J.M. (1942). Where is the sun?. Heat. Vent., 39, 59-61. 